\title{
CONNECTED AUDIENCE 2019 BERLIN, KONFERENCE, KTERÁ NABÍDLA EMOCE V BERLIINSKÝCH MUZEÍCH
}

\author{
TOMÁŠ DROBNÝ - PAVLA VYKOUPILOVÁ
}

https://doi.org/10.5817/MuB2019-2-9

„Emotions are complex constructions that include beliefs about the state of the World.

Some beliefs may be conducive to learning."

Maria Gendron

Rakouský institut KulturAgenda, Institut for Museums, cultural enterprises and audiences, připravil již podruhé v Berlíně, tentokrát ve spolupráci se Státními musei v Berlíně, konferenci s programem zaměřeným na další velmi aktuální téma současné muzejní pedagogiky. Berlínské Kulturforum hostilo ve dnech 4. -6. dubna 3. mezinárodní muzejněpedagogickou konferenci s názvem 3rd International Conference On Audience Research and Development, Connected Audience 2019 Berlin, s tematickým názvem The Role of Emotions in Museum and Cultural Experiences. ${ }^{1}$ Po vídeňské konferenci v září 2017, orientované na výzkum muzejního publika a berlínské konferenci v únoru 2014 s tématem video dokumentace v muzeích, se stala třetí konference KulturAgendy spolu s ř́jjnovou konferencí Hands On! ve Frankfurtu nad Mohanem jedním z vrcholů letošní nabídky konferenčních příležitostí pro muzejní pedagogy ve stř̌ední Evropě a přilehlém okolí. Tři dny konference byly nabity klíčovými tematickými příspěvky, workshopy, přednáškami a dílnami v sedmi sekcích. Společenský program nabídl jak seznamovací didaktickou hru s využitím tabletů

1 Connected Audience Conference 2019: The Role of Emotions in Museum and Cultural Experiences. In KulturAgenda. Institut for Museums, Cultural Enterprises and Audiences [online]. [cit. 2019-09-16]. Dostupný z www: < https://www.kulturagenda. at/connected-audience-conference-2019/>.

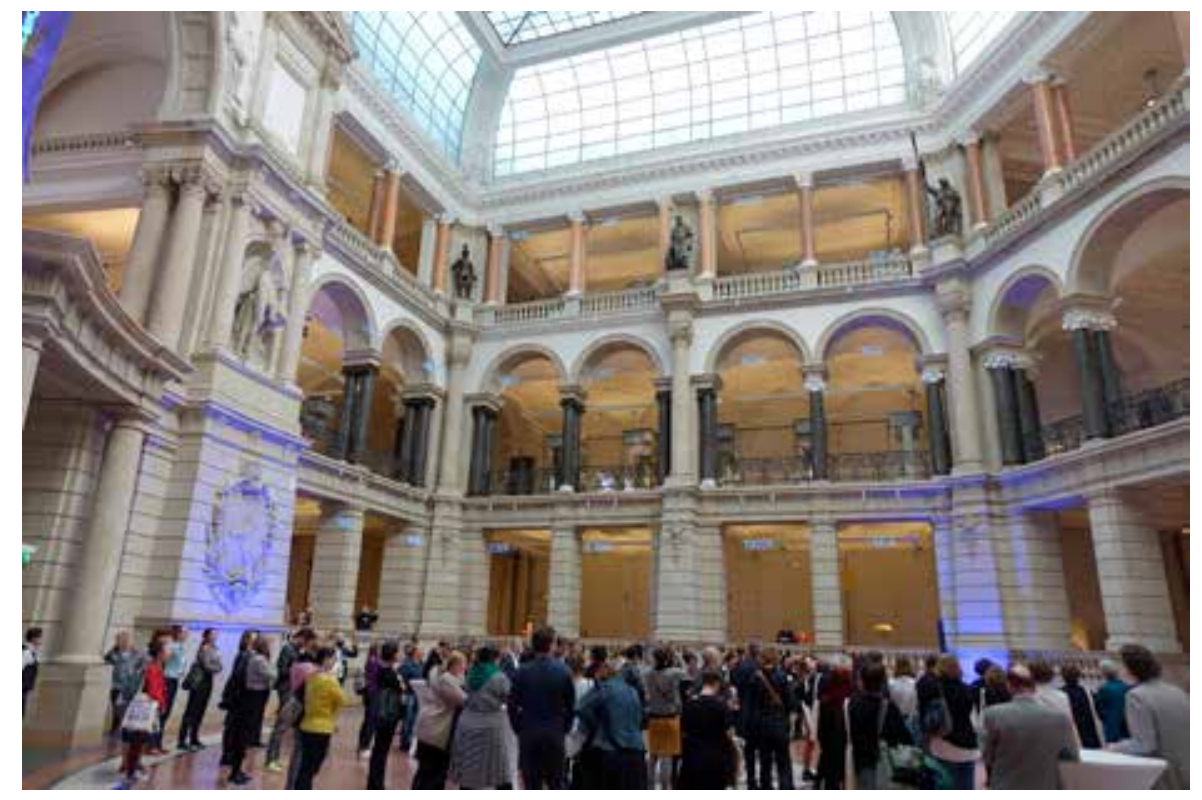

Obr. 1: Workshop v Muzeu komunikace Berlín (foto: Tomáš Drobný).

v Muzeu komunikace, tak večerní společenské setkání s občerstvením.

V Berlíně se sešlo téměř 300 zájemců ze 36 zemí, které přilákal zájem o poznání významu emocí v procesu lidského učení. Mezi přednášejícími se objevila řada známých jmen $\mathrm{z}$ oblasti současných muzejních věd, pedagogiky, psychologie a muzejní praxe: John H. Falk, Sheila Watson, Maria Gendron, Lisa Baxter, Martin Brandt Djupdræt, Paul Spies, Ewa Goodman, Marie Hobson, Tom Rockwell, Brinda Sommer a mnoho dalších. Neformální učení v muzeích se vyznačuje mnoha specifickými aspekty, které nelze jednoduše přebírat ze známého procesu školního vzdělávání, a tím důrazněji upozorňuje na důležitou roli mezioborových přesahů a kulturně sociálních souvislostí. Poznávání procesu lidského myšlení, zapojení tělesné stránky do procesu učení je jednou z významných oblastí, které v současnosti proměňují přístupy celého oboru pedagogiky. Klíčové príspěvky evropských i zámořských odborníků „Emoce a učeni“" Marie Gendron, „Muzeum jako místo, kde jsou emoce“ Sheily Watson a „Emoce a návštěva muzea" od Johna Falka nenechaly nikoho na pochybách, že nejen $v$ muzeích, ale i v celé edukaci v kultuřre sehrává emocionální 
stránka člověka-návštěvníka jednu $\mathrm{z}$ hlavních rolí.

Každý z účastníků konference si mohl poté vybrat $\mathrm{z}$ bohatého programu příspěvků a workshopů, které nabízely paralelní sekce jednání konference. Muzejní edukace není jen doménou tradičního muzejního prostředí, ale své uplatnění nachází i v prezentaci zpř́śstupněných památek. Britské královské paláce a historické osobnosti se prolínaly ve dvou příspěvcích, které nenechaly nikoho na pochybách, že právě emoce jsou tím, co $\mathrm{k}$ nim přitahuje pozornost většiny návštěvníků. „Šílenství krále Jiřího“ prezentované Rachel Mackay představuje program, který velice aktuálním pohledem zpracovává téma duševní nemoci. Emma Morioka ve svém vystoupení „Transformace minulosti: role emocí v zážitku návštěvníkưu nabídla objevování minulosti prostřednictvím storytellingu. Všezahrnující participace je spouštěcím mechanismem pro zážitky a poznání. Živé reakce a následující diskuse vyvolal příspěvek Anny Kovalevy s názvem „Formování srdcí, osví- cení myslí, získávání loajality“, ve kterém seznámila s Prezidentským muzeem Borise Jelcina v Jekatěrinburgu. Expozice představuje bývalého ruského prezidenta jako otce - zakladatele ruského liberálně demokratického politického uspořádání společnosti po pádu Sovětského svazu. K neobyčejně působivým zážitků patřilo též vystoupení Mirjam Wenzel z Židovského muzea ve Frankfurtu. „Poznávání židovské kultury všemi smysly" nabídlo nejen pohled do muzejních expozic, které uchovávají hmotné kulturní dědictví. Vypovídací schopnost neživých předmětů $v$ naší fantazii rozšiřuje poznávání prakticky vymizelé kultury v současném německém městě propojením smyslových vjemů spojených s historickou topografií. Hudba, chutě a vůně oživují náš vztah k judaismu v prostředí historického osídlení a reálií mimořádně působivým způsobem.

Celkový kulturně vzdělávací přínos konference ${ }^{2}$ podtrhla nejen setkání

2 Zveřejněné příspěvky z konference viz ownCloud [online]. [cit. 2019-09-16]. Dostupný z www: $<$ https://wolke.akis.at/index.php/s/EEND6PZQmAzyXuq >. v Muzeu komunikace Berlín, ${ }^{3}$ ale i prostředí moderní architektury Kulturfora ${ }^{4}$ a blízké budovy Berlínské filharmonie. Prémiovým zážitkem byla možnost návštěvy výstavy Mantegna a Bellini - mistři renesan$c e^{5} \mathrm{v}$ místě konání konference.

3 Museum für Kommunikation Berlin [online]. [cit. 2019-09-16]. Dostupný z www: < https://www. mfk-berlin.de/>.

4 Kulturforum [online]. [cit. 2019-09-16]. Dostupný z www: <https://www.smb.museum/en/museums-institutions/kulturforum/home.html>.

5 Mantegna+Bellini. Meister der Renaissance. In Staatliche Museen zu Berlin [online]. 2019 [cit. 2019-09-16]. Dostupný z www: <https://www. mantegnabellini.de/en/>.

\section{TOMÁŠ DROBNÝ - PAVLA VYKOUPILOVÁ}

Metodické centrum muzejní pedagogiky, Moravské zemské muzeum, Brno, Česká republika 